\title{
Entrepreneurship in Africa: A Comparative Study Between Ivory Coast and Benin
}

\author{
Koua Bertin Brou $^{1 *} \quad$ Prof. Meng Tao ${ }^{1.2} \quad$ Fatime Zahara Tahir Abderaman ${ }^{1.3}$ \\ Tossenou Codjo Barthelemy ${ }^{1.4}$ \\ 1.School of Business Management, Dongbei University of Finance and Economics, PO box 116023, 217 \\ Jianshan Street, Shahekou District, Dalian Shi, Liaoning Province, P.R China \\ 2.International Business College, Dongbei University of Finance and Economics, PO box 116023, 217 Jianshan \\ Street, Shahekou District, Dalian Shi, Liaoning Province, P.R China \\ 3.School of Accounting, Dongbei University of Finance and Economics, PO box 116023, 217 Jianshan Street, \\ Shahekou District, Dalian Shi, Liaoning Province, P.R China \\ 4.Business School of Liaoning University, Liaoning University, No. 66 Chongshan Middle Road, Huanggu \\ District, Shenyang, Liaoning Prov., China
}

The research is financed by Koua Bertin Brou, Author of this research paper

\section{Abstract}

Ivory Coast and Benin are both Africa's french speaking countries located in West Africa. Border countries and with high growth of the population, the living standards of the population become very difficult. In order to find a solution to regulate this negative impact and improve the living standards of the inhabitants, both governments focus on entrepreneurship. The objectif of this study to compare entrepreneurship in Ivory Coast and entreprneurship in Benin. For this reason, we did our research in Benin and in Ivory coast in 2018 and we found in both countries eight (08) main areas of E.A (commerce, teaching "public and private schools", transportation, communication including insurance, services, restaurants, bars, hair salon including hairdressers and barbers). To reach this goal, we have organised our research around three steps. The first step consist to compare the indicators of the both countries macroeconomics by focusing on their GDP, the level of employment, the educational rate and the use of energy. the second step was to compare the entreprenarial acivities in both countries, to show the strenghts and some weaknesses and how to solve this harsh phenomenal in order to make those areas more efficient. The last step was to promote the benefits of entrepreneurship for the population and the country. We know that our research is very useful for both countries and the whole africa, this is why in our study, we make recommendations to motivate inhabitants of both countries to create their own small businesses and we also encourage the Government of both Countries to give financial support to skilled inhabitant without revenues to help them to undertake to do their own activities to become independent.

Keywords: Entrepreneurship, Ivory Coast and Benin, Skills, small business

DOI: $10.7176 / \mathrm{EJBM} / 11-16-03$

Publication date: June $30^{\text {th }} 2019$

\section{Introduction}

In all the World, entrepreneurship is correlated to job propagation, modernization and the development of the economy. As we know, the approach of entrepreneurship has favourshed an impressionable role in the growth of the history of different businesses by involving two great schools: capitalism schools and industrialism schools (Hodgson 2000, Cooper 2004).

Even if there's no concise explanation of entrepreneurship, Timmons, (1995) said that entrepreneurship is the fact of establishing or grasping some opportunities and following those opportunities indifferent of the possessions such as goods highly regulated.

For Drucker, (2000), entrepreneurship involved "risks" for the principal reason that not almost all of the people who undertook the activities are familiar with what they do. Far away, he suggest that entrepreneurship is an usual job or profession. What he intends merely is that entrepreneurship is not the fact of making some projects or diagrams in a mind, but entrepreneurship starts by the action of establishing a new institution system.

Onuoha, (2008) defines entrepreneurship as the action of beginning new businesses in reaction to distinguish some opportunities.

Entrepreneurship is an active procedure to forge a formal fortune. But this richess is forged by people who take on all sort of risks by providing high worth for goods and services. The goods and services can be usual or unusual, but must have a high worth, so that a high skill must be useful (Ronstadt, 1985).

AK Yetisen, LR Volpatti and E Kamrani (2015) illustrate entrepreneurship as a fact of choosing virtually (in mind) one or several activities (businesses) and to materialize physically these activities in order to get profit.

In other ways, Piezunka and Henning (2012) define entrepreneurship as a strength and readiness of expanding, systematizing, administrating a business gamble with all forms of riks in order to earn benefits.

Ivory Coast and Benin are enriched with many opportunities of entrepreneurship, withal the plenitude 
execution of these opportunities, have been bedewed by the approval of many unsuitable government acts in both countries. So, many recommendations have been suggested to promote a wide growth of entrepreneurship throughout S\&M businesses, (Thaddeus, 2011).

The growth of entrepreneurship is a staple fact of the country economic growth and a solid factor of the eradication of poverty.

- Does entrepreneurship formally contribute to the growth of the economy in Ivory Coast and Benin?

- How does entrepreneurship push back poverty in both countries?

- What are the most important areas of entrepreneurship in Ivory Coast and Benin?

- In Which areas of entrepreurship both countries excel in?

- What are the components that make entrepreneurship more and less efficient in both countries?

Based on our simple intuition in view of the level of the economy in both countries before and after fostering entrepreneurship in both countries, we hypothesis that entrepreneurship gives a large contribution to the growth of the country economy. In view of the increasing of entrepreurship and the decreasing of poverty and the level of employment in both countries, We can also hypothesis that entrepreneurship helps to push back poverty and sove the problem of employment.

Entrepreneurship is a base of innovation and highly contribute to a change in all areas of productivity and the growth of the economy, (UNCTAB, 2014).

\section{Literature review}

At the beginning of our review of literature, we noticed three useful conductors of entrepreneurship in Ivory Coast and Benin.

Those conductors affect positively the self development of both countries: creativity, welfare capital and the institutional alteration.

The pertinence of these conductors and the result for self development of each country may merely be defined in the following lines:

1- Creativity: at beginning of the twentieth decade, Schumpeter (1913) has explained creativity as a generator of the economy growth, when Sunley and Martin (1999) carried on by saying that creativity is indispensable and vital for the self development of the countries. Cerativity brings out new point of view and opinion, the conception, adaptation and distribution of goods and high techs (Drucker, 1995). This situation can appear in an ecosystem where companies and other systems are consistenly involved in reciprocative study, (Cooke et al., 1999, p.1582). The area of creativity has been known as a significant parts of the competition between the countries, (Howells, 2006; Ruten, 2008; Cooke, 2005; Goessling, 2008). Rationally, the general ideas that try to give clear explanation of things which determine the competition between countries like modern industriousness areas, (Sabel,1985 \& 1990; Priore,1990), appointed as a system of flexible output (Markusen, 1997\&1998; Langlois, 1996; Glasmeier, 1992; Robertson, 1996) and creativity environments (Maillat, 1999; Crevoisier,2005) have toghether which they undertake creativity as a main conductor for all the activities of entrepreneurship and so the pratical development of the areas and the countries.

2- Welfare capital, defined as friendly framework in which people are built-in, (Coleman's, 1991, p.306), and sways positively the development of the different areas of the countries, (Putnam, 1994; Callois, 2008; Woolcock, 1999; Aubert, 2008; woodhouse 2007). Though there are many sorts of explanations of the positive development of welfare capital, (Adam and Westlund, 2011). For Schuller et al, (2001), the description of the function of welfare capital is different from the staple point of view of Bourdieu, (1984) who started with human as a focal point. For him, each person produces and utilizes welfare capital in mutual actions with other people. He carried on by saying that welfare capital could be, from one side, constructive by linking all the people having the same origins ans statues and connecting those people to outside people, (Woolcock, 1998 and O'Brien et al., 2006) and other side, coud be unconstructive by utilizing it to put out another people, (Landolt, 1997; Rubio, 1998; Portes, 1997).

Following Bourdieu, Coleman (1991) pointed out friendships among people. For him, welfare capital is is shown through the truth between many people and ensue friendly connections (Granovetter, 1974 and 1986; Burt, 1993).

By regarding the view of Bourdieu and Coleman, the author Putman (1996, p.68) clarifies the characteristics of social firms that make easier to coordinate and cooperate for reciprocal profit, and also points out the forms of organizations for personal devotion and divers kind of the activities of the third zone.

Despite the different argumentation of the three authors about welfare capital, all of them agree that the positive side of welfare capitale encourage the pratical development of the countries because, it creates a favourable place for doing entreprenarial businesses.

3- Institutional alteration, at the end, is known as an unceasing modification of the constraints of human invention which develop people exchange, (North, 2007, p.4) to the variation of the ecosystems (Aldrich,2007 ; Ruef, 2008). On the zone ladder, this stable variation of the systems promotes the establishment of positive overflow 
impacts among the various part of the firms, (Storper, 1998). These positive overflow impacts conduct in an ecosystem in that the actors rationally develop and harbor in the path of seeking modern technologies, goods, procedures to invent modern models or promote new porthole of occasions, (Martin, 2007 and sunley, 2007). Institutional alteration, from then, ensures that the firms and the zones can be possitively adjusted to the variation of outside circumstances, (Setterfield, 1994) that could shun denial " nail downs", (Grabher, 1994; Hassink, 2006; Lagendijk, 2001) and finally might conduct positevely the ways of development of different areas of the countries, (Sunley, 2007 and Martin, 2007).

In general, the promotion of creativity, welfare capital and institutional alteration and the fostering of the variation of the institutions are the principal tests for the favorable application of all the pratical development plan of actions, (pike et al., 2007).

\section{Methodology of research}

As we know, the research methology must be able to demonstrate the different variables linked to our research theme. For these reasons, we have collected many academic papers in the same area as our research subject. After the comparison of the indicators of the economy growth of both countries (Ivory Coast and Benin) focused on four (04) domains (Gross Domestic Product “GDP”, Level of Employment "LOE”, Educational Rate "EDR" such as School enrollment (primary, secondary and tertiary) and Use of Energy "UOE", we have interviewed some workers and Civil Servant from the most populated towns in both Countries in order to have more data samples collection. Our interviews are focused on the domain of entrepreneurship, such as the age workers began some activities, the description of their businesses, their high level of Education, how important Ivorians and Benineses find entrepreneurship, etc...

3.1.Entrepreneurship quantitative approach by using the Indicator of the Economy Growth.

3.1.1. Using the GDP growth from 1960 to 2015

As we know, the year 1960 was the sunrise of the indepency of both countries (Benin and Ivory Coast). Compared the Gross Domestic Product (GDP) growth helped to know the macroeconomy of the countries. From the data collection on worldbank website, we draw ourselves all the graphes below through excel. So, from the graph 1 we draw through excel, we have a good view of both countries GDP growth.

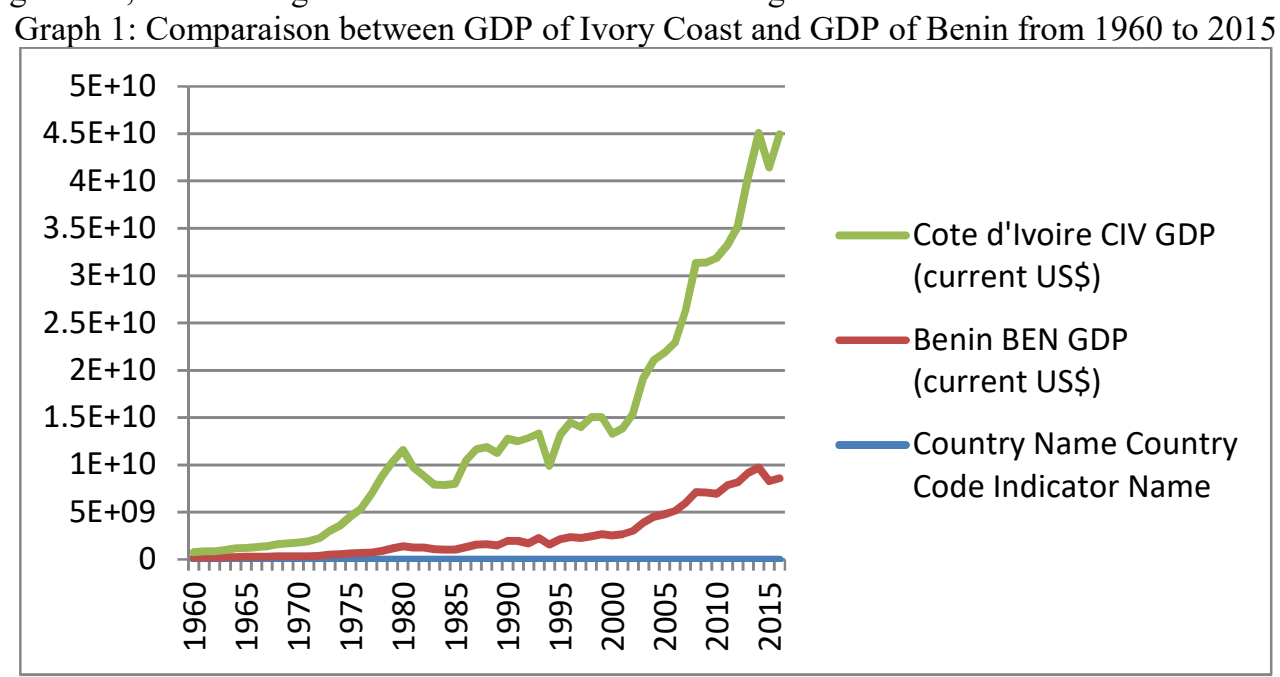

Sources: data.worldbank.com

From this graph, we can show the percentage of the GDP growth for both Countries with the graph 2. 
Graph2: The annual GDP Growth (\%) from 1960 to 2015

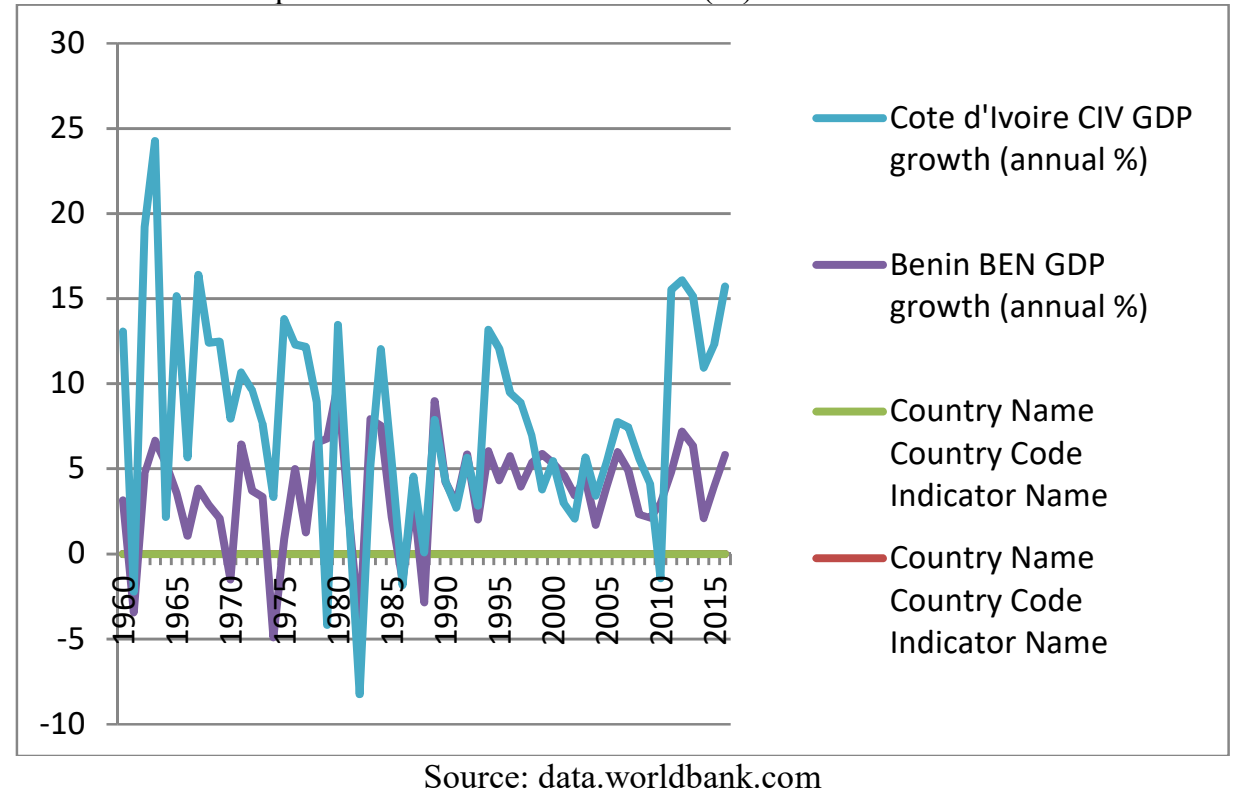

3.1.2. Using the Level Of Employment (LOE) of Benin and Ivory Coast

The level of employment is another criteria for the country macroeconomy. Data.worldbank.com reveals the percentange of the level of employment of the both countries from 1991 to 2017.

We represent those percentage with the graph 3

Graph 3: employment (\%) from 1991 to 2017

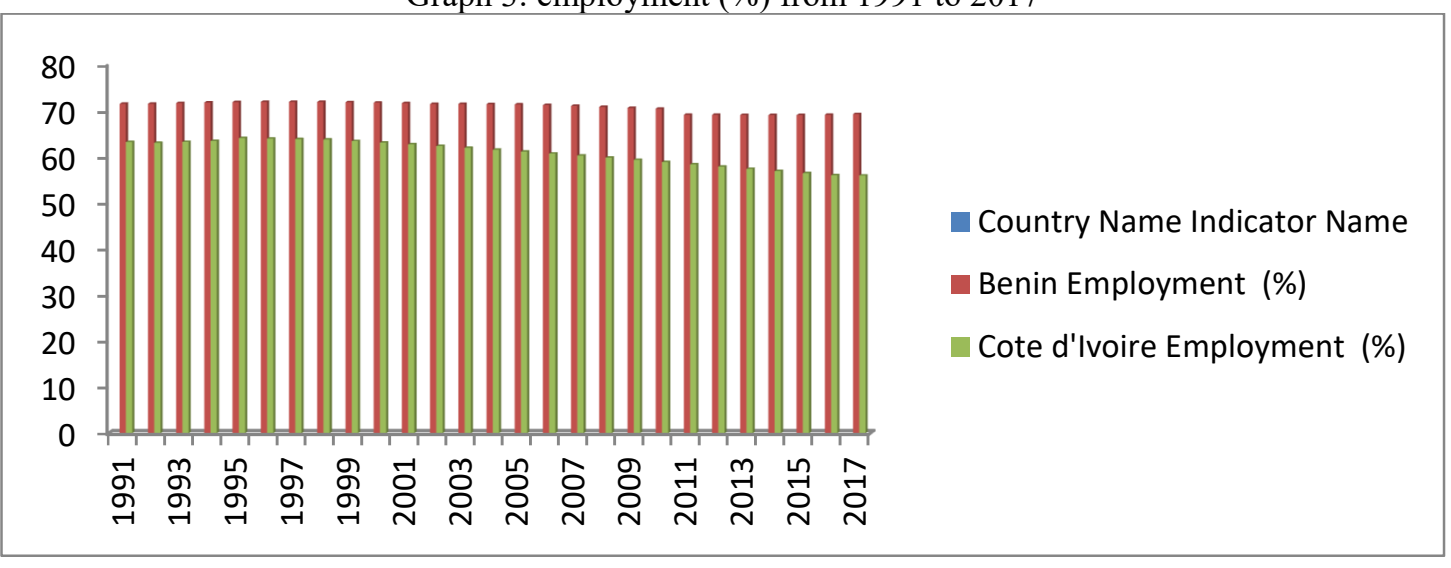

source: data.worldbank.com

3.1.3: Using of the Energy (UOE) kg of oil per capita from 1971 to 2014

The use of Energy also determines the development of the country. By knowing the use of Energy, we can find the development of the country. the graph 4 gives a good sight of that. 


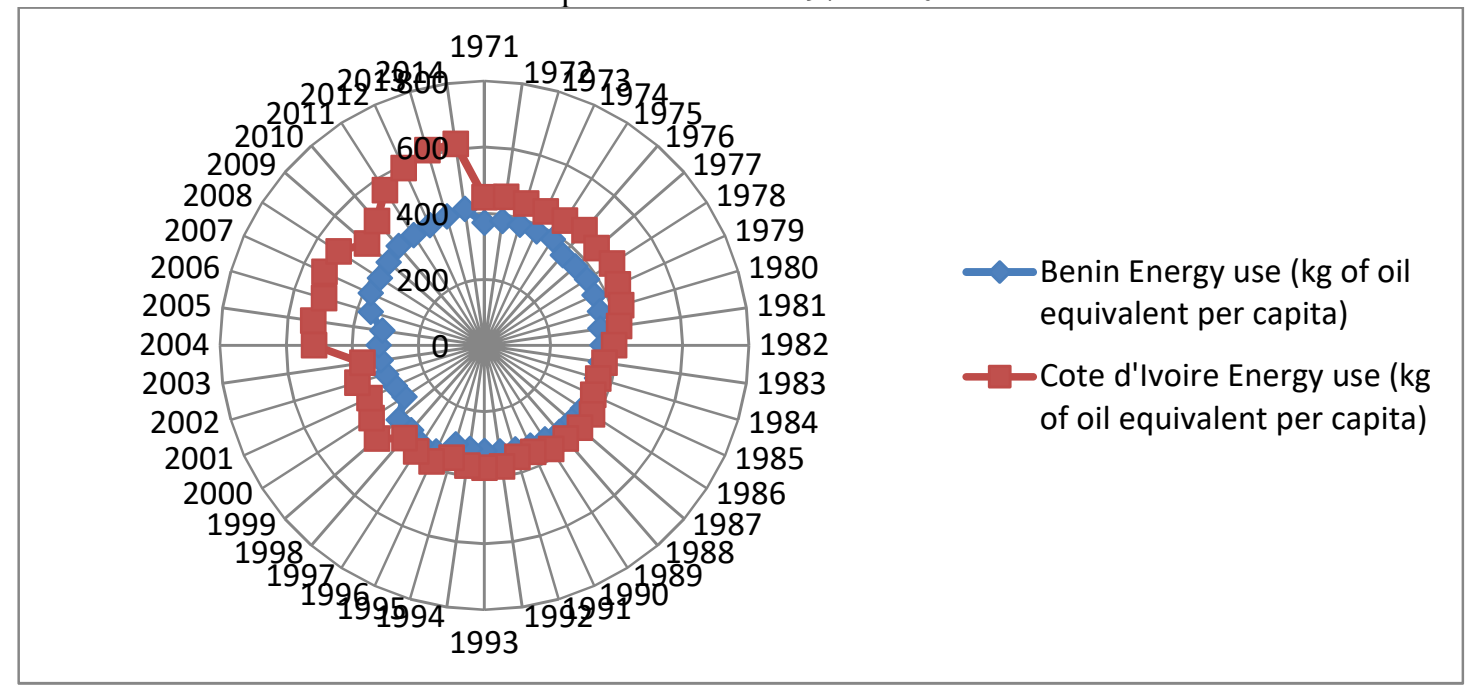

Source: data.worldbank.com

3.1.4: The Educational rate (EDR) from 1971 to 2015

We draw the graph for EDR by using the level of the school enrollment. We focus on three sectors : primary enrollment, secondary enrollment and tertiary enrollment. The graph 5 shows the level of EDR.

Graph 5: EDR from 1971 to 2015 by using primary, secondary and tertiary enrollments.

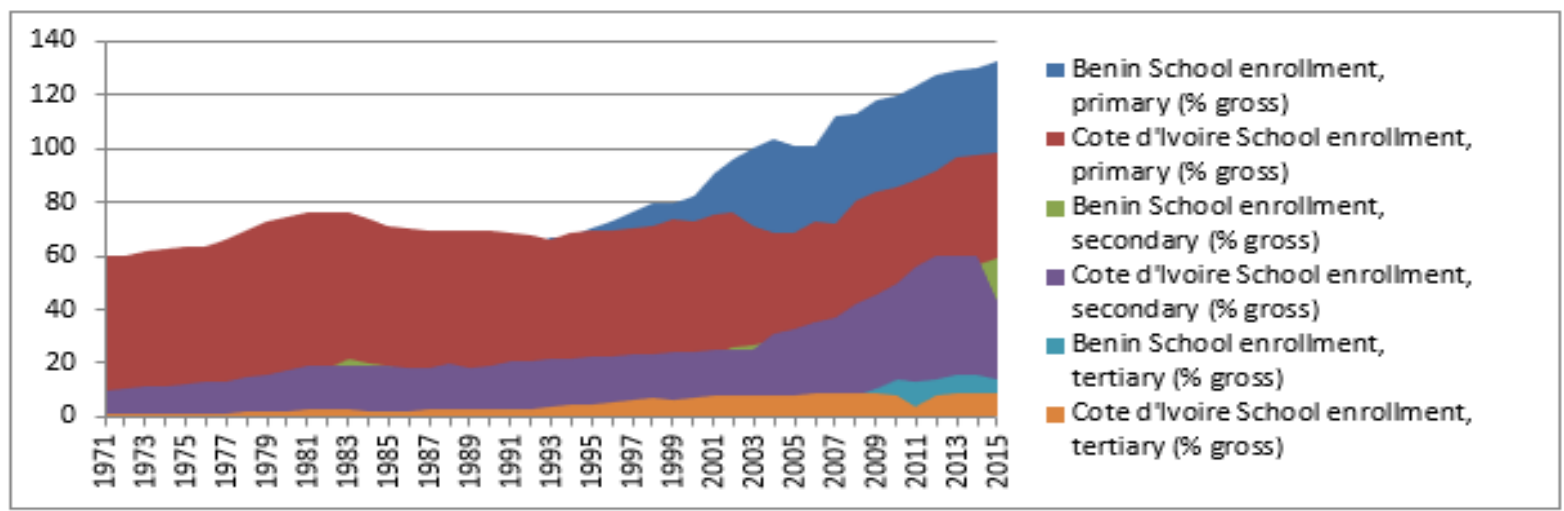

source: data.worldbank.com

3.2: Entrepreneurship: Pratical activities in Benin compared in Ivory Coast.

3.2.1: Classification of the areas of entrepreneurship between both countries

In todays life, people who haven't some degrees, people who have not high school level can create their persononal businesses like educated people. In table 1, we focus on eight (8) domains of entrepreneurship (bars, commerces, communication including insurances, hair salons for men and women, restaurants, services, teaching in private or public schools and transportations. These areas are useful for inhabitants of both countries.

The table 1 gives a clear vision between entrepreneurship in Benin and Ivory Coast by focusing in the 8 domains of entreprenarial activities.

Table 1: Classification of the differents areas of Entrepreneurship

\begin{tabular}{lcccc}
\hline & \multicolumn{3}{c}{ Percentage (\%) } \\
\hline Bars & Benin & Ivory Coast & Benin & Ivory Coast \\
Commerces & 12 & 11 & 7.69 & 7.05 \\
communication including insurance & 29 & 21 & 18.58 & 13.46 \\
Hair salons & 16 & 19 & 10.25 & 12.17 \\
Restaurants & 13 & 12 & 8.33 & 7.69 \\
services & 10 & 16 & 6.41 & 10.25 \\
teaching (publics and privates school) & 22 & 23 & 14.1 & 14.74 \\
transports & 34 & 37 & 21.79 & 23.74 \\
Total & 20 & 17 & 12.82 & 10.89 \\
\hline
\end{tabular}


From table 1, we draw the graph 6 of the classification of the eight areas of entrepreneurship in Benin and ivory coast

Graph 6:Classification of the differents areas of entrepreneurship

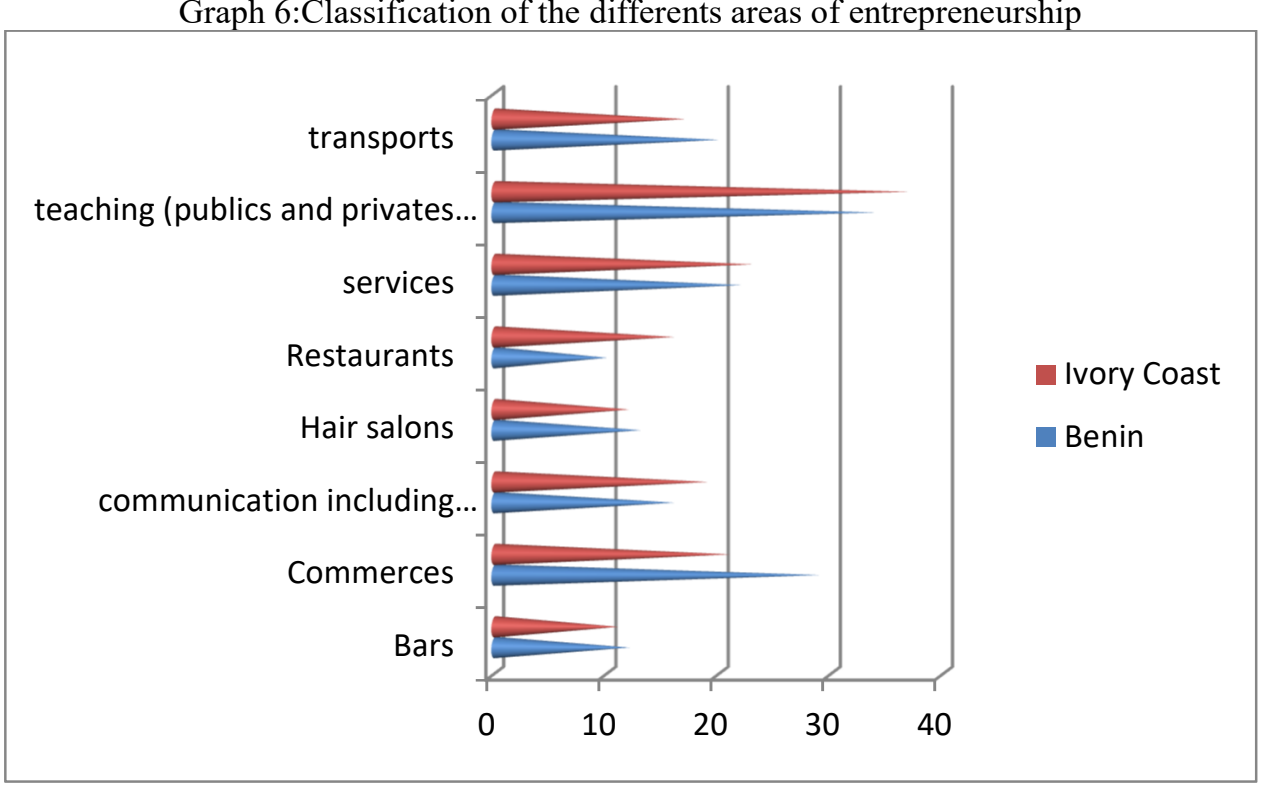

source: data.worldbank.com

Each of the different area is leading by un person or people called General managers and conducting by a person or people called experts and qualified workers. Table 2 give the number of people who represent each domain of entrepreneurship.

Table2: People who Represent each domain of entrepreneurship in Benin and ivory Coast.

\begin{tabular}{|l|c|c|c|c|c|c|c|c|}
\hline & \multicolumn{2}{|l|}{$\begin{array}{l}\text { General } \\
\text { Managers }\end{array}$} & \multicolumn{2}{l|}{$\begin{array}{l}\text { Experts / } \\
\text { specialists }\end{array}$} & \multicolumn{2}{l|}{ Qualified } & \multicolumn{2}{c|}{ TOTAL t } \\
\hline & BEN & IVC & BEN & IVC & BEN & ICV & BEN & IVC \\
\hline Bars & 1 & 1 & 7 & 5 & 4 & 5 & 12 & 11 \\
\hline Commerces & 5 & 5 & 12 & 9 & 12 & 7 & 29 & 21 \\
\hline $\begin{array}{l}\text { Communications including } \\
\text { insurances }\end{array}$ & 1 & 2 & 7 & 8 & 8 & 9 & 16 & 19 \\
\hline $\begin{array}{l}\text { Hair salons (barbers and } \\
\text { hairdressers) }\end{array}$ & 1 & 1 & 5 & 4 & 7 & 6 & 13 & 12 \\
\hline Restaurants & 1 & 2 & 4 & 6 & 5 & 8 & 10 & 16 \\
\hline Services & 3 & 4 & 6 & 7 & 13 & 12 & 22 & 23 \\
\hline $\begin{array}{l}\text { Teachings (public and private } \\
\text { school) }\end{array}$ & 1 & 1 & 12 & 17 & 21 & 19 & 34 & 37 \\
\hline Transportations & 2 & 1 & 8 & 9 & 10 & 7 & 20 & 17 \\
\hline TOTAL T & 15 & 17 & 61 & 65 & 80 & 73 & 156 & 156 \\
\hline \% & 9.61 & 10.89 & 39.1 & 41.66 & 51.28 & 46.79 & 100 & 100 \\
\hline
\end{tabular}

From the table 2, we draw the grath 6 below to show a nice view of the survey. 
Graph 7: Classification of domain of entrepreneurship: Benin VS ivory Coast.

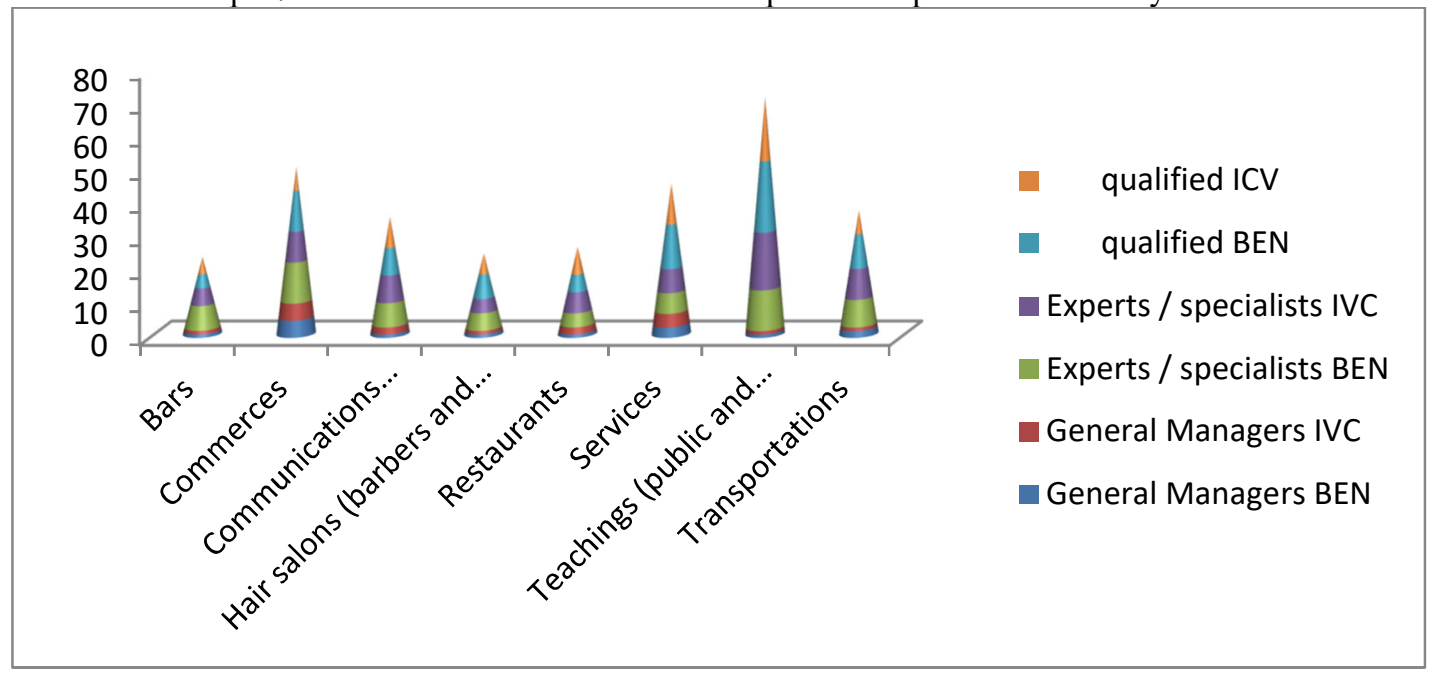

source: data.worldbank.com

3.2.2. Categories of entrepreneurs age in Benin compared to ivory Coast.

We have also focused on the age of people who practise entreprenarial activities in Benin and Ivory Coast. The result of our survey is reported in table 2 .

Table 2: Category of the age of people who practise entreprenarial activities

\begin{tabular}{lllll}
\hline Age & \multicolumn{2}{c}{ number } & \multicolumn{2}{c}{ Percentage (\%) } \\
\hline & BEN & IVC & BEN & IVC \\
below 24 & 14 & 22 & 8.97 & 14.1 \\
$\mathbf{2 4 - 2 9}$ & 42 & 48 & 26.92 & 30.76 \\
$\mathbf{3 0 - 3 9}$ & 57 & 41 & 36.53 & 26.28 \\
$\mathbf{4 0 - 4 9}$ & 25 & 30 & 16.02 & 19.23 \\
above 50 & 18 & 15 & 11.53 & 9.61 \\
total & 156 & 156 & 100 & 100 \\
\hline
\end{tabular}

From the table 2, we also draw the graph 7.

Graph 7: Category of the age of people who practise Entreprenseurship activities

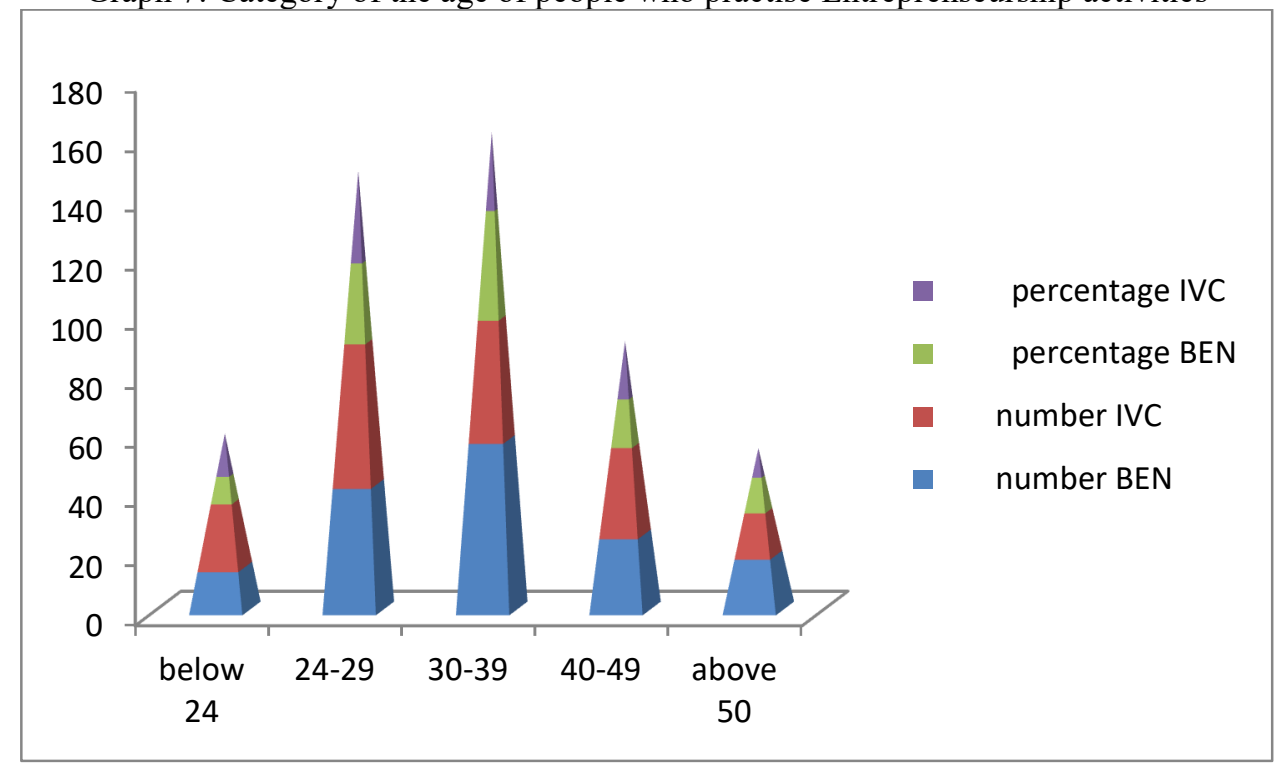

source: data.worldbank.com

\section{4-Results ans findings}

4.1. The indicator of the country macroeconomics.

According to the indicators of a country macreoeconomics, the economy of Ivory is stable and it grew since 1960. GDP in that year grew around $82 \%$ attaining $360 \%$ in 1970 . But the anormal situation in the country pushed back 
the economy and the development of the country. in view of the report in worldbank, GDP of ivory Coast had shrunk by from $360 \%$ to $28 \%$ in 1980 and $22 \%$ in 1990 .

In 1994, the devaluation of the official currency (XOF) of Ivory Coast and all the african countries using the same currency by fifty per cent (50\%) had occasionned the inflation growth by $26 \%$, but between 1996 to 2000 , the rate also felt again.

The unstable situation of the country in 2000 has favourished the increasing of the poverty and the decreasing of the GDP.

Because of the national emergency politics, the economy of Ivory coast still growing since 2005 until now by annual growth estimated at 5\%. Compared to the economy of Benin which had a little growth from 1960 to 1995, we constact the growth of GDP by 5\% in 1996 and reaching 5.4\% in 2012. This growth is due to the export of Cotton from Benin to Europe which represents $40 \%$ of the GDP.

The problem of unemployment still one of the scourge of both countries. But we constact a little progression of Ivory Coast compared to Benin. Since the new republic in Benin, things we constact the decrease of employment due to the new regulations about taxes. Many foreign entreprises are interested to Benin and the establishment of the companies has improved the level of recruitment. In 2003, the poverty line accordind to Gini coefficient in Benin was 36.5 while the poverty line of Ivory Coast was 28.7 in 2003.

The use of Energy and the enrollment in primary, secondary school are dominated by Ivory coast but we notice that the tertiary enrollment is dominated by Benin.

\subsection{Pratical activities}

In our survey done in the both countries (Benin and Ivory Coast), we focused on eight sectors of entrepreneurship and 156 surveyed entrepreneurs. They have given an eyesight view on their activities (table 1 and graph 6). We found that In Benin, bars occupied $7.69 \%$ of the activities, while in Ivory Coast, for the same activity, we noticed $7.05 \%$. The sector of bars is dominated by Benin, because the taxe on alchool and sweet drinks are lower than in Ivory Coast. That encourage people in Benini to create their own bars in order to deal with their own businesses. The sectors of commerce (18.58\%) and hair salons $(8.33 \%)$ is also higher in Benin than in Ivory Coast $(13.46 \%)$ and $(7.69 \%)$, but we notice that the area of communication including insurance is more developped in Ivory Coast $(12.17 \%)$ versus $10.25 \%$ in Benin. The development of this activity in Ivory Coast is due to the high population of Ivory Coast. The activity of transportation occupied $12.82 \%$ of the activities in Benin while the activity occupied $10 \%$ of entrepreneurship activities in Ivory Coast. The port of abidjan is one of the important port in west africa, so many goods such as cars are conveyed to Ivory Coast before sending to the countries without Ports, like (Burkina Faso, Mali....). The Government of Ivory Coast focused on taxes on transportation to maintain its economy higher. Teaching and restaurants are also higher in Ivory Coast. They respectively represent $23.74 \%$ and $10.25 \%$ of the entrepreneurship activities. Compared to Ivory Coast, the same entrepreneurship activities are low in Benin. They represent $21.79 \%$ and $6.41 \%$ of the entrepreneurship activities in Benin. As we noticed, according to data.worldbank.com, primary and secondary enrollments are higher in Ivory Coast than in Benin. That increase the number of teaching in Ivory Coast. The new politics of the Government of Ivory Coast to make school free in order to help all boys and girls to go to has stimulated the area of entrepreneurship. According to the statistics made by UNESCO, primary school net enrollment ratio was $56.9 \%$ from 2008 to 2012 . This rate has strongly increased since 2012 until now, reaching 68\%. The high schooling of boys and girls has occasionned the recruitment of teachers.

From 2005 until now, around 5.000 teacchers are recruited each year in Ivory Coast.

We have linked our survey to the educational background of people who practise entreprenarial activities. We found that most of the entrepreneurs in ivory coast are the most educated. Around $10.89 \%$ are General Managers and $41.66 \%$ are experts, while only $9.61 \%$ are General managers in Benin and $39.10 \%$ are experts. This situation can be explained that in ivory Coast, most of the entrepreneurs are educational background for the activities they do. And they received a training for their entreprenarial activities areas.

Despite Ivory Coast has most General Managers and experts and specialists, we noticed that Benin has the most qualified entrepreneurs 51.28\% versus Ivory Coast entrepreneurs which represent $46.79 \%$.

From table 2 and graph 7, we found that $14.1 \%$ of people under 24 years old in Ivory Coast are doing their own activities. This percentage of the age of people who practise entrepreneurship activities in Ivory Coast is higher than Benin $8.97 \%$. It is merely because, in Ivory Coast, entrepreneurs began their activities before 24 . So there are less young entrepreneurs in Benin than in Ivory Coast. There is a real growth for people between 24-29 in both countries, $30.76 \%$ for Ivory Coast and $26.96 \%$ for Benin. This significant growth can be explained by the fact that people leave school at this age because they are graduate. Some of them create their own businesses and the others are employed by the public or private sector. While the percentage of age of people who practise entrepreneurship activities strongly increases for the age $30-39$ by $36.53 \%$ and decreases for the age $40-49$ by $16.02 \%$ in benin, we noticed that in Ivory Coast, it decreases sharply from $26.28 \%$ a to $19.23 \%$. At the age between 30 to 39, people in Benin practise entreprenarial activities than in Ivory Coast and we noticed the inverse for people 
between 40 to 49 . At this age, people begin to become old and weak. They practise less and less activities because they need to be healthy.

Finally, at the age above 50, less people in both countries practise entreprenarial activities. But we noticed that people in Benin, $11.53 \%$ at this age practise more activities than people from Ivory Coast, 9.61\%.

As we know, the success of entreprenarial activities is due to a nice environment and the politics made by Governments. Even if there are skilled people and people with vision, the entrepreneurship couldn't be developped in a country without nice atmosphere, real Government politics to foster it and the lack of regulations to well organize it.

\section{5-Discussion}

In our study, we compared entrepreurship in Benin and Ivory Coast by focussing in eight sectors (bars, commerce, communication including insurance, hair salons, restaurants, services, teaching "public and private schools" transport) and how the entreprenarial activities pushed back poverty and increased the living standards of people from both countries. With the selected people and entreprenarial activities,

we showed the difference educational bacground of the entreprneurs. We also focused on the different categories of ages that people practise entreprenarial activities to know that at what age people practise the most entreprenarial activities. Our research has an important benefit for the government of Benin and Ivory coast because it compares the different macroeconmics' indicators at the important level.

We hope that our research will allow many people in Ivory Coast and in Benin to increase their knowledges about entrepreneurship and the importance of entreprenarial activities for the growth of the country economy and its development by pushing back poverty. Despite the significant value of our research for the population of both countries, it also shows some limits. In view of a comparative study between both countries, finance and the distance were the contstraints of our study, because, as we live in china, we need to use internet and other means of communications, such as cell phones, to communicate with people in Benin and Ivory Coast. We also faced to the problem of unavailability of some important actors of entreprenarial activities, sometimes due to their occupation. But, we did our best to conduct as well as we can to inclose this research using the tools and the limited resources that we had in our hands.

\section{Conclusion}

Since the sunrise of independence of Ivory Coast and Benin in 1960 until now, we can testify that entrepreurship increases with many benefits for inhabitants from both countries. We have focused our research on the four (04) indicators of a country macroeconomics such as GDP, employment rate, Educational rate and the use of energy and eight sectors of entreprenarial activities. From our survey done in both countries, we can affirm that Benin excels in some areas of entrepreneurship like bars, commerce, hair salons and transport than Ivory Coast. But in another areas like communication including insurance, restaurants, services and teaching in public and private schools, Ivory coast excels in than Benin. As we know, Michelacci (2015) believed that educational background was the staple success of entrepreneurship, our survey showed that another factors like the category of age and the environment play a significant role in entreprenarial activities. As neighbouring countries, Benin and Ivory Coast can learn from each other obout entrepreneurship, so some actions can be taken by both countries to foster the collaboration.

\section{Recommendation}

In our research, we just used four indicators of a country macroeconomics because of the short time of our survey. We also focussed on eight entrepreneurship activities in both countries. And at the sunset of our research, we talk about the benefits of entrepreneurship for Benin and Ivory Coast. We recommend for further research, to focus on many indicators of a country macro economics like infant mortallity, the poverty rate, the inflation etc..

We also recommend for further research to explore more than eight areas. So we encourage them to scrutinise another areas of entrepreneurship like social entrepreneurship and the Government funds to promote entrepreneurship. They can also make a comparative study between more than two countries.

For the Governments, we recommend to flatten entrepeneurship activities by voting some laws to promote entrepreneurship.

\section{References}

Adam and Westlund [April 2011], Is entrepreneurship better for the development of the Economy? Creativity. IMT Press Journal Creativity, Governance and Winter Mondialisation. Vol.1 No 1, 98-108

AK Yetisen, LR Volpatti and E Kamrani [2015], Entrepreneurship and the Development of Economy in West Africa: The Path is carrying on, 240-256

Aldrich and Ruef, [2008], Economy Growth and Entreprenarial activities. The modern Policy and Directives for Execution, This Day Live Newspaper, February 12th 2007 
Bourdieu [1984], The growth of entrepreneurship on the creation of Employment, AAS Journal of Management Support, Vol. 4. No.1 Page 102-106

Callois and Aubert [2008], Empirical study on Entrepreneurship Behavior. Journal of small business, 24-36

Coleman [1991], friendship capital in the establishement of People capital, American Journal of Sociology 95 , S96-S121

Coleman [1992], Entrepreneurship and the growth of the Econom: Drawbacks and Perspectives,.306

Cooke et al.[1999], Entrepreneurship: Useful in the creation of Richess, Just begin now, 1582

Drucker [1995], Pragmatic Issues: From Thinking to Reality, Polity Press, Cambriedge, 47

Drucker [2000], Policy and Tools for managing small business, Journal of HTM Research, 12-16.

Grabher, [1994], Hassink, [2006]; Lagendijk, [2001], Entrepreneurship: Fruitfull, Unfruitful and devastating. Journal of political Economy, 890-899

Granovetter [1974] \&[1986]; Burt [1993], Creativity as the path of Human Life for Business, JSB Management, $32-45$

Hodgson [2000], Cooper [2004], Moral Interpretation of entrepreurship: Are there some inequalities between entrepreneurs? Journal of Business Ethics 20, 230-240

Howells [2006]; Ruten [2008] Cooke [2005] Goessling [2008], Entrepreneurship as the Origin of The increasing of the Economy, The review of the Economy growth, Page 15- 34

Landolt [1997]; Rubio [1998] Portes [1997], The family role in entreprenarial activities: A practical study, Journal of small business, 50-60

Maillat [1999] Crevoisier [2005], Development and entrepreneurship: The best way of using External support, Journal of Business Venturing 5, 122-128

Markusen [1997\&1998]; Langlois [1996]; Glasmeier [1992] Robertson [1996], Managing the stress due to entrepreurship, Havard Business review 60, 45-61

Martin [2007] and sunley [2007], To be "Authentic" about young people entrepreneurship in West africa, The series of the Ruffin 6, Page 6-48

Michelacci [June 25th ,2016]: “Are they all like Bill, Mark and Steve? Educational, first step for entrepreneurhip (PDF), EIEF Retrieved November 28, 2016.

North [2007], Exhaustive knowledges on entreprenarial activities, Journal of the culture of enterprise 13, 4

Onuoha [2008], First entrepreneurs in West africa, The growth of small business, 14-18

Piezunka and Henning [2012], Stategical entrepreneurship, The strategy to make decision for the creation or modern venture, $248-253$

pike et al., [2007], The Institution builders: the Study of Individual entrepreneurship skill, Policy Study journal, Page 57-81

Putman [1996], The Future of entrepreneurship as a study topic, Academy of Management Review, 68

Putnam [1994], Africa's gold path, A functional study, 97-100

Ronstadt [1985], The Governments actions toward the improvement of entrepreneurship in developing countries, G.J.of Business Research, Vol.8 No.1 Page 101-112

Sabel [1985 \& 1990]; Priore [1990], The Fundamental Knowledge of entrepreneurship, Academy of Management Review, Vol.7, 33-37

Schuller et al [2001], Entrepreneurship and New World Construction in a New Ecosystem, M.Journal of S.C, Vol.4 No.15, 352-341

Schumpeter [2010], Understand Entrepreneurship and its benefits for African's society, Vanguard Newspaper, (March 10, 2010)

Storper [1998], Clarify the entrepreneurship direction and Connect it to efficiency, Academy of Management Review, 22(2), 138-176

Sunley and Martin [1999], The Growth of Entreprenarial activities and Job Generation in West Africa: Troubles and Perspectives, Universal Journal of EGS, Vol 2. No.5, 89-103

Sunley, [2007] and Martin [2007], The Gloom side of Entreprenarial activities, BJM No 14, Vol.4 Page 320 351

Thaddeus [2011], Balance to measure Creativity, Human Communication research, Journal of Business Management Vol.5, 59-64

Timmons [1995], The moving of all sort of rights: The efficacity of entreprenarial companies competition, S.E.Journal, Vol.6 No.4, 149-163.

UNCTAB, 2014, World Investment Report 2014, ISBN 975-94-2-1-121878-01

Woodhouse [2007], Survey and Creativity, Alternative option for Entrepreneursip, S.E Journal Vol.2 No.3, 1215 